\title{
"Threads of the Orientalist/Procolonial Discourse in John Updike's Novel The Coup"
}

\author{
FAROUQ REZQ BEKHIT SAYYID \\ College of Science and Arts, Qurayyat Campus \\ Jouf University, Saudi Arabia \\ $\&$ \\ Faculty of Languages and Translation \\ Al-Azhar University in Cairo, Egypt \\ frsayyid@ju.edu.sa
}

\begin{abstract}
This paper is an attempt to point out how John Updike's novel The Coup (1978) conforms to the traditional Western notions and conventions about Africa and Africans. The methodology of this paper involves a textual analysis of The Coup whereby significant passages from the novel are cited and elucidated with regard to the ideas of Orientalism as a discourse to reveal how Updike employs such a discourse to render a distorted image of Africa and African cultures as he draws heavily on stereotypes and traditional prejudices as embodiment of the darker side of the human psyche. At the same time, this paper is meant to point out the seemingly authoritative stance of Updike through the sources he consults and the techniques he utilizes to endow his negative discourse with a tone of authority, knowledge, and expertise. This seemingly authentic stance provides Updike with the means to adopt a superior, Western voice of power in the creation of truth with regard to Africa as a nation and to the East/West relationship as a dichotomy. As the novel relates, Updike not only justifies the American intervention in Africa, but he does injustice to the humanity of the African personality which he diminished through racist stereotyping. It is, therefore, through utilizing this Orientalist/postcolonial approach and relevant data that this paper concludes that Updike displays absolutely no insight into the characters involved in this novel. Instead, he weaves African colonialism, Islam, the Cold War, socialism, capitalism, and exploitation of every variety into a novel with a few too many characters that are explored just enough to make them into two-dimensional cartoons of real human beings. As such, Updike's The Coup is no more than an attempt to assert the authority of the West, specifically the United States, as a superpower that surpasses the Soviet Union in its control over Africa and African resources.
\end{abstract}

Keywords: Africa; Updike; Imperialism; Postcolonialism; Orientalism; Otherness; Exoticism

\section{INTRODUCTION}

In The Coup, John Updike breaks away from the confines of suburbia to the vastness of the African continent. It is Updike's first novel set outside the U.S., with Brazil (1994) the second, which followed over one and a half decade later. The Coup was Updike's attempt to make sense of what he had seen in Africa which he visited as a Fulbright lecturer during the time the book is set (197374). In fact, the decade of the 1970s became a watershed for the Fulbright program in Africa. As the Fulbright program was and, in many respects, continues to be evaluated according to the status of the scholars who have been grantees, Updike was, according to Adelaide Cromwell (1987), "the only nationally prominent American Fulbright alumnus who went to Africa" (101) in 1973. As the second American Lincoln Lecturer of the Fulbright program, Updike, Cromwell (1987) notes, "conducted seminars and informal sessions with groups in Ghana, Nigeria, Tanzania, Kenya, and Ethiopia". These lectures "stimulated interest in courses in American literature in African universities, which by then had become a priority of the Board" of Foreign scholarships (p. 96). Also, during the past two decades preceding The Coup, Updike has reviewed with sympathy and wit 
books written about Africa. "Africa, explored and excavated and neo-capitalized as it now is", he writes in one review, "remains... an invitation to the imagination" (Picked-Up Pieces, p. 351) ${ }^{1}$.

In form, The Coup is the memoirs of Hakim Félix Ellelloû, the now-deposed President of Kush, a fictional sub-Saharan country suffering from a long-term drought ${ }^{2}$. The memoirs, written sometimes in the first person and sometimes in the third, recount his final year as President, with numerous digressions upon his years as an expatriate student in America at McCarthy College in Franchise, Wisconsin, during the 1950s. Now in exile, Ellelloû recounts the story of his rise and fall and of his perpetual struggle to avoid the ambiguous gifts of American aid. He fears not only the junk food but also the forces of secularity and materialism that will ultimately make of his beloved Kush a spiritual wasteland. He virtually stands alone in his resistance to the so-called benefits of American civilization, toward which he admits ambivalence.

Just as Kush is a composite African nation, Ellelloû is a composite African leader; he is a dictator of the sort common in many African and Mediterranean countries. In a conversation with Charlie Reilly (1978), Updike describes his intention in the novel as the creation of "a kind of echoing effect" (132). Moreover, giving his invented setting a realistic quality, Updike provides a wealth of detail about the geography, culture, and history of Kush. This mythical country gradually reveals itself as a vessel containing information about actual African nations and cultures. In his interview with the Observer just a few months before his death and during the 2008 American presidential elections, Updike endorsed the then nominee Barack Obama and suggested that the prospective leader of the free world might benefit from reading The Coup. On this occasion, thirty years after its publication, Updike reveals the particular African despot he had in mind when he created Ellelloû: "I'm for Obama, 100 per cent... I really think Obama would regenerate this wornout country... For Obama I'd recommend a novel of mine called The Coup. It's about an imaginary African country where the dictator pretends to hate the U.S., actually went to college here. The politics were based on Gaddafi-what's he called, not Mohamed, Muammar, right? The joke is how unlike Obama my character is!" (Interview with Peter Conrad, 2008, p. 10).

\section{ABUSE OF SOURCES: AFRICAN FANTASY}

Arguably, Western writings on Africa point out how the images of Africa in these writings, including Updike's novel, have not changed greatly from antiquity to the present. Africa has always been viewed as the land of mystery and lavish exotica. In the vision of Western reader, Africa is either the abode of the 'noble savage' or a land enveloped in the darkness of barbarity and animalism. When seen as the realm of the 'noble savage', Africa is considered a refuge from the rush and roar of the Western world. When seen as a land sunk in primal barbarism, it is thought to present to the Western reader hazards which can only be overcome with heroic attributes. Thus, for many Western authors, and Updike is not an exception, the appeal of Africa is its "Otherness", its difference from the contemporary West. To some extent, what a Western author finds in African settings is influenced by the attitude that he/she has about African places. Authors expecting to find magic in Africa discover a magical Africa and those seeking to discover elements of their heritage find their history in African settings. Moreover, increased American awareness concerning Africa, Africans, and African affairs since World War II is the result of historical, political, and economic events. The drive for independence that swept Africa after World War II and the Civil Rights Movement in the United States greatly increased public interest in Africa and African cultures.

As if actual African landscapes, nations, and cities do not provide adequate literary settings, Updike sets The Coup in an invented African nation meant to represent the characteristics, values, 
and conflicts of the entire continent. One may argue that Updike's utilization of a fictional African nation to be the setting of his fiction on Africa is intentional. In a way, Updike seems to use Africa as a backdrop on which to project a white Western male fantasy that says more about America than Africa. Responding to Ellelloû's pronouncement that "Africa held up a black mirror to Pharaonic Egypt, and the image was Kush" (Updike, p. 14), Deborah McGill (1979) argues that one might say of The Coup [that] it holds a white mirror to postcolonial Africa, and the image is Connecticut" (p. 89) ${ }^{3}$. Thus, Updike's creativity, if it can be called so, is to put his imperialist attitudes and procolonial impulses in the mouth of a black African protagonist, Colonel Ellelloû, erstwhile President of the arid, impoverished, landlocked country of Kush. As a result, Jay Prosser (2001) faults Updike for his view of skin and race in The Coup as well as in Brazil. In "Under the Skin of John Updike: Self-Consciousness and the Racial Unconscious", Prosser (2001) asserts that "[i]f Updike was ever America's literary consciousness, it was a white consciousness. His fictional work has consistently made of blackness an "Other". Tellingly, Updike has represented blackness most substantially outside America, and he has represented it in antithesis to whiteness" (p. 579). In another essay, "Updike, Race, and the Postcolonial Project", Prosser (2006) also assumes that "blackness for Updike stands as the other, love or hatred, guilt or fear, a measure of white American consciousness" (p. 76), implying that every positive characteristic of white masculinity is defined against an equally negative aspect in Updike's black characters he utilizes in such works.

Viewing the novel solely from a realistic ground, The Coup is not without certain substantial problems. Many of Updike's descriptions and information about certain details in the novel are not that convincing. His geographical details, for instance, are confused and vague locales. Instead of offering an artistic insight into the universal human condition in Africa, Updike, as Irving Leonard Markovitz (1980) observes, "merely transposes his jaded philosophical prejudices onto a totally inappropriate setting" (p. 538). Unlike some Western novelists who wrote about Africa, Updike did visit the continent in 1973. His Fulbright lecturing tour in Africa lasted only four weeks. When asked about his aim behind this trip, the author related his experiences with the kind of enthusiasm all travelers exude. The decision to go to Black Africa was made for a number of reasons, according to the novelist: "I had never been there... I thought of it as a part of the world that had a different angle on things... I am interested in the Black American and the relationship he has to Black Africa, and I was particularly interested in seeing an underdeveloped area that is not overpopulated" (Interview with Robert Waite, 1973, p. 67). This, in itself, should give The Coup more credibility, but Updike's account on Africa and African people is something else. In addition, references to the factual drought in the Sahel in the early 1970s, quotations from the Ever-Glorious Qur'ān, and an explicit hostility towards America should lend Updike's narrative an air of authenticity. Yet, Updike's short visit would not suffice to recreate actual feelings of the people as well as the places he writes about.

Apparently, Updike's information and account on Africa, as expounded in The Coup, derives mainly from his utilization of some books he listed in the 'Acknowledgments' section in the novel. Updike turns to such books to supplement his short trip to Africa for the writing of the novel. Along with a series of scholarly studies consulted for the occasion, Updike lists the National Geographic magazine, children's books, Beau Geste, and travelers' accounts. Donald Greiner (1992) reports how "eclectic reading shapes the background of The Coup" and how Updike "also used books to travel to Africa before he thought of The Coup. As a regular reviewer for the New Yorker, he has written essays about [many] African authors...” (p. 32).

In addition, Updike acknowledges other numerous sources for his African information, including works by fellow writers on Africa. This is in addition to the Ever-Glorious Qur'ān, which 
perhaps Updike was handling for the first time in his career ${ }^{4}$. Yet, mediation through and negotiation among these materials are second-hand and likely to be biased because most of these accounts on Africa are far from being objective. Updike's Africa, therefore, is, like his Kush, an Orientalist/imperialist creation; and so, in part, is his increasingly debased and contemptible America. Thus, one should note, before anything else, that Updike paid a great price due either to his confidence in books, or his wayward imagination. He has succeeded in creating a comic, even hilarious satire, but he occasionally falls into what some readers can see as confusions. One has the impression that Updike, at some moments, misuses his sources. Worst of all, he selects a deluded and fanatical military dictator as the figure to whom he will stretch his fantasy about Africa and Africans. Updike, thus, seems to write with the pre-established objective to satisfy the average Western reader's expectations of the grotesque images of Africa. This, in turn, results in a fictional work replete with procolonial impulses and Orientalist overtones.

\section{AFRICA: THE EMPTY JUNGLE}

Images of Africa as "empty" and devoid of a history has been perpetuated by Western traders, missionaries, adventurers and explorers, as well as by Western media and men of letters. Novels written on Africa often paint the picture of heathen peoples who thrive in backward traditions and practices and superstitions. Bernth Lindfors (2001) points out how "racial stereotypes were powerfully conveyed to the common man in the West through popular literature, especially the adventure fiction set in various corners of the colonial empire (p. 54). Lindfors refers to the role imaginative literature plays "in disseminating farfetched racist ideas" to English readers and how "such value-laden discourse, directed at a mass audience, probably does "more collective harm than the published papers of scientists" (p. 54).

For Updike, writing in the age of American expansionism, Africa signifies absence and emptiness. The association of the African continent with a prehistoric vitality and emptiness serves both to deny its implication in history and to justify its appropriation by the patriarchal-imperial gaze. In The Coup, Kush is entirely fictional, but construction is used to rule. Updike created a country; he created a people; he created a name, much like the imperialists who came to Kush from his country. On the spectrum of geographical accuracies, Kush is a sort of an Orientalist's construction. The land is empty, destitute, and poverty-stricken. Diseases are spreading everywhere. The details in The Coup point to some well-known French- speaking African states: Niger, Chad, and others. Ellelloû can be taken for many African dictators as well.

Consequently, Updike offers the reader a governable imperialist construct in a typical Orientalist fashion. In addition, he offers a geography in which to fit that construct. An important element of the construct presented by Updike is the imagery of the desert and sterility. It is a state of mind as well as a geographical locale. Formerly known as 'Noir' under the French colonialists, Kush is a fabricated country or it is what Updike (1978) calls "an idea of Kush" (p. 21). Created by imperialism amidst warring and nomadic tribes for whom national borders are meaningless, it is nonetheless real. Because Ellelloû is an unreliable narrator, his observations cannot always be trusted. But since he claims that he copies information about Kush from an 'old Statesman's YearBook" (p. 16) and because he has no reason to lie about the geography and economy of his country, it seems reasonable to take his narrations for granted. The list of sources at the start of the novel, the apparent Third World sensibility, and the superficial acknowledgement of weighty issues, mask the presence of Updike, the procolonialist, who firmly believes in the continent's blankness and innate corruption. Just as no coup actually occurs to topple Ellelloû, so the novel does not represent a whole new direction for white writing about the black continent. 


\section{L: The Southeast Asian Journal of English Language Studies - Vol 26(2): 67 - 80 \\ http://doi.org/10.17576/3L-2020-2602-05}

A careful analysis of the The Coup reveals that it is merely Updike's fantasy. The American novelist provides openness to real-world facts-historical, socioeconomic, statistical, geographical, linguistic, scientific, political, esoteric-very much in line with the realist conventions. Moreover, the realistic creation of the geographical location begins in the very first pages of the novel: "In area Kush measures 126, 912,180 hectares. The population density comes to 00.03 per hectare... There are twenty-two miles of railroad and one hundred seven of paved highway... In addition to peanuts are grown millet, sorghum, cotton, yams, dates, tobacco, and indigo... The natives extract ingenious benefits from the baobab tree..." (p. 15). Also, the mixing of the real and the imagined are at work in a historical setting. In the neo-capitalist "puppet states of Zanj and Sahel" (p. 13), the former is a made-up country while the latter is not a modern state, but an actual region afflicted with drought below the Sahara in West Africa. The fictitious and distorted geographical sites are offset by real ones, such as Lyons, Marseilles, Dakar, Zanzibar, Chinese Turkestan, etc. The actuality of real places provides anchoring points to a tangible world for the reader. The geographical boundary of Kush, bordering on the realm of both the real and the imagined, is a parallel to other aspects of this African novel, an agglomeration of fact and fiction. Imagination, however, overshadows the doses of facts in this novel. The recognizable geographical and historical names are lost in the sea of fantasies and archetypes. Updike had neither the ambition nor the ability to paint a realistic image of Africa. Obviously, he was not well-informed enough to give an accurate, or, at least, objective account on the places he writes about. Pinak and Lalbakhsh (2019) argue that an objective representation of the "Other" "requires the breakdown of the boundaries of Self and the "Other" that are the boundaries which the discourse of travel writing entails" (p. 43). Updike, however, chooses to remain somehow in the traditional vein of fictions that make Africa a dream-like invention; a fantasy!

After discerning Updike's fingers controlling the strings of the narrative, the task of enumerating the imperialist/Africanist elements of The Coup becomes much easier. Ellelloû consistently refers to the blankness of the continent while his imagery and conduct illustrate the corruption of it. Thus, it is clear that the tendency of American fiction to represent Africa as an empty land is a tradition that is dozens of decades - and perhaps centuries - old. Curiously, for a discussion of the representations of Africa and the so-called Third World in The Coup per se one has to refer back to Joseph Conrad's novella Heart of Darkness (1899), a monumental work which traces the representations of Africa and Africans. As Conrad has shown, Africa to the imperialist mind is "an idea", a blank or dark space on the map, a story told by a white man on the deck of a boat in the metropolis. Recalling his childhood love of maps, Charles Marlow-the narrator of Conrad's novella—says, “... at that time there were many blank spaces on the earth" (p. 11). One of the largest blank spaces on young Marlow's map was Africa. For this, some critics fault Conrad for filling Marlow's blank map with invented nations and peoples. Chinua Achebe (1988), for instance, refers to Heart of Darkness as a work that projects the image of Africa as "the other world," the antithesis of Europe and therefore of civilization, a place where man's vaunted intelligence and refinement are finally mocked by triumphant bestiality" (p. 252). Achebe further maintains that the image of Africa as the "Other" is "the dominant image of Africa in the Western imagination" (p. 261).

Like Conrad's Marlow, Updike (1992) has once admitted to have "always been attracted to hidden corners" and chosen Africa because it was "the emptiest part of the world I could think of" (cited in Greiner, 141). His Kush is a Saharan nation that suffers from prolonged drought and famine. Ellelloû calls it a "land of delicate, delectable emptiness," separated from the Mediterranean and the northern border by an "ocean of desert" (p. 14). It is a fabricated country 
where there is just an idea of it. Echoing the prevalent imperialist association of the continent with mortality, Ellelloû uses a death's-head as an image for his country which suggests on a map "an angular skull whose cranium is the empty desert" (p. 16). Throughout, the actual borders of Kush are ever vague, to say the least. Moreover, the border of Kush in the northwest is "nine- tenths imaginary" (p. 43). This depiction of Kush is nothing more than a reflection of what takes place in Updike's mind. Thus, Updike's mind, as well as the entire nation of Kush, stands as physical entities that the imperialist nations, in this context the United States and the Soviet Union, hope to occupy and take over.

As such, the novel's epigraph from the Ever-Glorious Qur'ān, "Does there not pass over man a space of time when his life is blank", introduces the concept of the void". The quotation from Herman Melville at the start of the fourth chapter, "Beneath the stars the roofy desert spreads Vacant as Libya" (italics Updike, 141), reinforces this void. A desert does not have individual or distinguishing characteristics, but rather a void of individuality, which is applied in kind to Africans and Muslims. This implies the idea that the people who dwell in the desert should be dealt with in the same way; that is, collectively. Thus, Melville's epigraph, being the only Western and American one among all the epigraphs cited by Updike in more than one place in the novel, draws attention not only to the symbols of stars and vacant blank desert, but it also draws one's attention to the link between America and Africa. Strikingly, the chapter which Melville's epigraph heads abounds with Ellelloû's reminiscences of his four-year study in the United States during the 1950s and the associative juxtaposition of America and Africa; city and desert. Once in America and while discussing his final exam with Professor Craven about a course on African history, Ellelloû answers this professor's complaint that there seemed to be "something missing" in his answers by suggesting that this may be "the very African ingredient" (p. 215). Thus, an anecdote from Ellelloû's college days in Wisconsin drives the notion of blankness back home in Africa.

Updike's Africa, therefore, is an invented place upon which fantasies can be projected. It becomes, as Malini Schueller (1991) states, "a paradigm of an essentialized and homogenized Third World awaiting interpretation and representation by the West" (p. 116). Barry Amis (1982), quoted as an expert on Africa in an article by Joyce Markle (1982), believes that the sociological and geographical details of The Coup and also asserts that the novel's true voice is neither African nor black as "[t]here is nothing in the novel that is authentically African. The customs are not African, the language is not African, and the characters certainly are not African...they are not characters that any African would recognize" (p. 298).

Furthermore, the amalgamation of facts and fantasy in The Coup gives a lion's share to myths and exotica. In a sense, the depiction of Kush is complicated by its mythical associations. This land of darkness and emptiness is plagued by a prolonged drought. Using the myths of the Fisher King and Oedipus stories, Updike turns the drought into a symbol of the spiritual waste of this land. His exploitation of such ancient myths and transferring them into Kush is seen by Schueller (1991) as a "suggestion that the problems of the [so-called] Third World can be explained only through the "universal hermeneutics of the West" (p. 117). Furthermore, Updike's manipulation of mythical association also provides evidence for the pointlessness of the heroic deed in a distinctly non-heroic culture such as Africa. In addition to being empty and destitute, Updike depicts Kush as a harsh land where people must struggle with the environment to survive. In more than one instance, Updike represents the topography of the country as being so severe that it causes illness and disorientation. Diseases, therefore, have been repeatedly employed in the narrative to demonstrate the severity of this African country: "Among the natural resources of Kush perhaps should be listed our diseases - an ample treasury which includes...malaria, typhus, 


\section{L: The Southeast Asian Journal of English Language Studies - Vol 26(2): 67 - 80 \\ http://doi.org/10.17576/3L-2020-2602-05}

yellow fever, sleeping sickness, leprosy, bilharziasis, onchocerciasis, measles, and yaws" (pp. 1617).

Updike is even unconvincing because his African protagonist writes about bizarre situations, unlikely people, and philosophical abstractions remote from the continent, made in America. The Coup is replete with implausible episodes such as Ellelloû's drinking the urine of one of his wives - Sheba - when they were in the desert seeking the cave of the King's head: "Seeing me stare, Sheba laughed and, without abandoning the rapture of kola-chewing, urinated on the desert sand. In my madness of thirst, of love, I reached forward with cupped hands to rescue some of the liquid, though I knew from tales of other travelers that urine was as acid as lemon juice. It haunted my mouth for a burning hour" (p. 159). In another instance, Ellelloû has a sour mouth from holding burning coal to prove his authenticity as a dervish: "I had, more than once, held a hot coal from the campfire in my mouth and mimed swallowing it. Such things are possible, when the needful spirit transfixes the body, and fear does not dry up the saliva" (p. 41).

The implausibility and bizarreness of such acts provoked native Africans who stand up to right the wrong and put things in their right perspective. In his paper presented to the 1979 MLA Convention in San Francisco, Barry Amis (1982) charges Updike with the fictionalization of Africa and faults him for the inaccuracies and misinformation he ascribes to Kush, and Africa at large. Amis makes it clear that Updike constructs Kush out of elements from very different parts of the continent and considers The Coup as a pastiche of historical fallacies:

The area [Updike] describes is one which might include parts of present-day Mali, Niger, and [Burkina Faso].
In this area one does not find Indian shops (which are a feature of East Africa) nor does one find souks (which
are a feature of North Africa). Juju is not a feature of the lives of the overwhelmingly Moslem [Muslim]
population and Tuaregs [Twareg] do not have slaves. Young women do not walk around "utterly naked" in front
of their parents and others, driving a Mercedes through the Bad Quarter is an automotive impossibility.

(Cited in Markle, pp. 283-84)

Arguably, such inaccuracies and historical fallacies disguise the Western man's fantasy that lies below the surface of The Coup. A closer analysis of the narrative reveals Kush as an amalgam of an imperialist/Orientalist imagery. The novel is no more than a narrative of the Third World well-rehearsed in Western imagination. Malini Schueller (1991) assumes that the historical plot of The Coup is "a thinly veiled fantasy of expansionism, disguised as the familiar rationalization of the inability of the Third World natives to govern themselves" (p. 115). She further asserts the assumption that this novel, and others, functions "to legitimate an imperialist discourse that denies the political existence of the Third World" (115). Speaking to the same effect, John Cullen Grusser (1992) insists that Updike's narrative "projects a white Western male fantasy" (p. 103) about Africa and Africans. In line with both Schueller and Grusser, Irving Leonard Markovitz also points out that Updike offers his readers "a type of white man's burden in his version of an African point of view" (p. 538). Hence, Updike's task in The Coup is to bring these African nomads and villagers whose way of life he sees archaic, wasteful, and destructive and seize this opportunity to urbanize them.

\section{ELLELLOÛ: ROOTLESS LEADERSHIP AND POLITICAL MISMANAGEMENT}

The mythologizing of Africa in The Coup is heightened by allegorical ingredients. Ellelloû himself is an allegorical figure. He represents himself, too, as exotic, as a caricatured African created by American mass media. The fact that Ellelloû is the product of rape also adds to the mythologizing of his figure: "We know this much of him," Ellelloû says of himself: "he was short, prim, and 
black. He was produced, in 1933, of the rape of a Salu woman by a Nubian raider" (pp. 17-18). On account of his father being a predator and his mother being a woman of the clan Amazeg, Ellelloû inherited a violent temperament and will live by the code of violence all his life. When rejected by his friend Oscar X in the U.S., Ellelloû feels his curse as "a blast of heat upon his face, the heat whose first wave had been, in infancy, the absence of his father" (p. 209). In addition to the absence of his father, Ellelloû's existence is also marked by another absence. According to him, "all of the nubile women in our land of Kush, above the lowest social stratum, carry a dagger with which to stab their own hearts if their honor is compromised, ere the rapist can work his will. My mother, alas, had had no such implement...” (p. 199). Thus, Ellelloû's very existence is a consequence of his mother's lack of a dagger, and his life can be taken as a substitute for that dagger. In a way, Updike seems to say that African rulers are so rootless and so isolated that fortune determines which individuals will be swept into and out of office.

Furthermore, Ellelloû comes in The Coup as alienated, corrupt, irrelevant, and powerless. In his attempts to evade his true personality, he is largely unknown in his nation and on his various trips he often travels in disguise. He begins to feel like a guest in his own country and the population comes to regard him as crazy. He further views himself as a child, as a college boy in an alien country, as an ambitious though idealistic young soldier. In addition to murdering his adversaries, Ellelloû grows increasingly insane, in the process putting personal whims before the good of the country. He would rather have Kush starve to death than become contaminated by the forces of materialism. As a result of his madness, he loses touch with political realities. Like Kush, he, despite his polygamy, is sterile. Thus, what at first appears to be a realistic novel from the perspective of an African proves to be a white Western male fantasy.

Ellelloû, the bearer of revolutionary ideology and the only proponent for Kush's political and cultural independence, has in fact no vision at all. Although he appears to be serious about his religious, political and social ideals, and although he harbors deep corrosive hostilities, Updike presents him as a demagogue. He is turned into an emblem by the fiery radicalism he attaches to his religious beliefs, and his overall political ideology. The language of the narrative is an index of Ellelloû's stereotypical cachet. He appears in public in his military uniform, his eyes barred from the reality of his native Kush by enduring designer sunglasses. His denunciations of Western economic domination are devoid of any tangible connection to the lives of people in Kush. They are mere invectives in keeping with mass media versions of insane African rulers. In the midst of a prolonged drought that has ravaged the country, Ellelloû rejects the mounds of breakfast cereal sent by the United States with the following tirade: "The people of Kush reject capitalist intervention in all its guises. They have no place in their stomachs for the table scraps of a society both godless and oppressive. Offer your own blacks freedom before you pile boxes of carcinogenic trash on the holy land for Kush!" (p. 51). Ellelloû, as Greiner (1992) notes, "manipulates language the way he plays with masks". Greiner (1992) further assumes that Ellelloû's constant donning and discarding of masks and rhetorical stances "confuse his sense of self", and hence, "the recurrence of such catchwords as 'cultural revolution', 'imperialism', 'neo-colonialism', are invaluable words that have been overused by many post-colonial African demagogues" (p. 37).

One cannot but largely disagree with Greiner in this respect because Ellelloû's satirical outbursts serve effectively to depoliticize and thus circumscribe all ideas of revolution and independence in post-colonial Africa. Capitalist intervention and oppression, which are clear-cut realities faced by developing countries, become mere set jargon here in their indiscriminate usage to describe food aid for famine. Thus, African rhetoric-capitalist intervention, oppression, freedom - is introduced into Updike's novel only to evoke and invalidate its legitimacy. In 
addition, Updike's depiction of Ellelloû seems to make a mockery of the all-too-real human tragedy that afflicted the Sahel. Does Ellelloû care about human life at all, or only about the right alignment of the human spirit? He burns the tons of food which would have fed thousands of starving people, implying that a righteous death is better than a contaminated life.

A common reader of The Coup knows for sure that most of the starving people of Kush do not know anything about the lofty concept of capitalism; that they would welcome the junk food the American aide is bringing; that the drought-devastated Kush is not so holy; and that the catastrophe that has struck the land will not be remedied by the dictator's pedantry and fiery speeches. The language makes Ellelloû a prototypical demagogue and a perfect symbol of hypocrisy. Ironically, Ellelloû claims to be against American nationalism, while in fact his second wife is American. He advocates Islam as the religion of his state, but he beheads the old King, Edumu, the embodiment of old religious values, in the most unholy manner. Consequently, Ellelloû's presidency has created an unpleasant situation in his country. Yet, in depicting African leadership that way, Updike, as Markovitz notes, "reinforces images in the popular [Western] mind", which are just as "erroneous", and gives "support to established politicians who are wary of ideologues and anxious to "do business as usual" (p. 536).

Relying on binary oppositions, asserting Africa's blankness, and equating it with a fantasy world, Updike links the capriciousness of Ellelloû's approach to the putative randomness of Africa. Kush is a nightmare of bloated bureaucracy, greed, corruption, and unrealistic "Islamic fundamentalism", while the past is a haven of peace and natural abundance. Yet, Ellelloû's defeat at the end of the novel at the hands of American-backed forces is an indication on the part of Updike that America does not support dictatorship. Updike chooses not to mention the fact that the United States supported, both materially and militarily, certain despotic regimes in Africa as well as in many parts of the world. America has, over time, also been supporting many undemocratic governments as a means of creating a productive environment for the exploitation of Africa's natural resources. When Ellelloû is finally ousted and exiled in France, the American press hailed the event. The final indication of his insignificance comes when he bargains for a pension for himself and his family and moves to the South of France to write his memoirs which become The Coup. Ellelloû, therefore, proves to be no more than a disguise through which Updike can write a narrative about the Third World apparently from a position of proximity rather than distance, while continuing to codify the native as aberrant, exotic, denatured, and primitive.

But who is Ellelloû? It seems possible that he might not be an African. On the one hand, Ellelloû's African scenes contain frequent errors of facts - geographic and others-and seem often strangely devoid of concrete detail. On the other hand, Ellelloû's American scenes are much more vivid, detailed, and accurate. His knowledge of Africa seems approximately equivalent to that of an observant tourist. Ellelloû, thus, appears to be so much of a political and religious crusader that his status goes beyond than of a simple President. Having started his memoirs with an epigraph from the Ever-Glorious Qur'ān, he ceaselessly documents his writing with Qur'anic verses, turning it into an apology for Islam on the one hand and an outspoken dismantling of Christianity and other faiths on the other. Updike presents Ellelloû as a paranoid ideologue, puritanical and obsessed with hatred of anything American. "Eradicate tourism", he thinks to himself, "eradicate property ...eradicate theft" (italics Updike, pp. 117-118). Writing of his early attempts after the revolution to purge Kush of Western elements, Ellelloû at this point in time vigorously prosecuted the cause of cultural, ethical, and political purity in Kush:

Any man caught urinating in a standing position, instead of squatting in the manner of Mohamet [sic] and his followers, was detained and interrogated until the offender could prove that he was a pagan and not a Christian. 


\section{L: The Southeast Asian Journal of English Language Studies - Vol 26(2): 67 - 80 \\ http://doi.org/10.17576/3L-2020-2602-05}

Overzealous enlistees from the swaddled north seized and flogged young girls on the banks of the Grionde, under the impression that their bare breasts imitated decadent French fashions. The flocks of secretaries working within the corridors and anterooms of the Palais $d^{\prime}$ Administration des Noires were enjoined from wearing tight skirts and blouses...

Moreover, a form of 'Islamic' Marxism that structures the politics of Kush under Ellelloû takes a more fundamentalist turn. The dictator once spots a Muslim woman "wearing freaky sunglasses," and then she disappeared into a doorway before he could halt and ask her at what "illegal and subversive market she had made her purchase" (p. 113). The girls in the Kush capital of Istiqlal attend the "Anti-Christian High School" (p. 21), which is dedicated "to the extirpation of the influences of Christian mission education, and a prison for the politically aberrant" (p. 15). He is further haunted throughout his travels by whiffs of alien hair tonic, such as the one that would blow from the open doorway of a barbershop in Wisconsin, U.S.

Even though Ellelloû's second wife, Candace, somehow renounces the West she is still an emblem of Western values. She has remained a Christian and used to mock the Colonel's bigotry and the phoniness of Islamic rituals. "Christ," she challenges him, "if you don't think I wouldn't have been over-goddam-joyed to go back with the rest of them where you can have a drink of water without lifting out the centipedes first and bowing toward smelly Mecca five times a day and having to kick starving kids out of your way every time you walk the goat, you have another think coming" (135). Her regular standoffs with her husband are metaphors of the East-West conflict (Islam and capitalism), the whole drama being enlivened by the introduction of Marxism. In moments of high emotion, she calls on Christ as a witness, while Ellelloû calls on Allah. The incompatibility between the West she represents and the ideologies Ellelloû is a crusader of, is further reflected through their failure to have children together. Ellelloû interprets this "sterility" as a result of Candace's unwillingness to carry a black baby. The incompatibility is so strong that she asks him to divorce her, which he does at the end of the novel. More importantly, the failure of democracy in Kush despite the Ellelloû's democratic training, and the irrational politics he practices has much to do with the "noble savage" figure that has always characterized Western literatures on Africa.

\section{AFRICA: ENDEMIC VIOLENCE AND CONFLICT}

As it is the case with many novels featuring Africans or Orientals, The Coup is replete with many terrible acts of violence and barbarity. These acts of killing and torture involve both whites and blacks. In one of his several paranoiac fits, Ellelloû orders that an American Foreign Service employee, Donald Gibbs, be burned on the pile of the junk food he is bringing to the famished Kushites, as a sign of his rejection of imperialism. The killing or immolation of Gibbs is the first act of blood on the part of Ellelloû. This American emissary and what he stands for are part of the old order which must be swept aside for the sake of Ellelloû's vision of a new dawn of freedom, independence, and national dignity for Kush.

Yet despite the atrocity of this act and Gibbs' apparent humanitarianism, Updike gives his readers the impression that the American envoy primarily dies in the name of American capitalism, and not for a higher humane cause: "To his credit, the young American...did not cry out for mercy...but, rather, climbed to the pinnacle and, luridly illumined, awaited the martyrdom for which there must have been, in the training for foreign service... some marginal expectation and religious preparation" (pp. 53-54). By the same token, the reader finds Gibbs' acceptance of death contradictory with his sense of arrogance and cynicism preceding his death, especially when he vents his extreme chauvinism on Ellelloû, "This [food] isn't refuse, pal-it's manna..." (p. 49). 
Before long, he is cursing Ellelloû, courting the death sentence upon himself: "We know this country's socialist and xenophobic, we know Ellelloû's a schizoid paranoid; we don't give a f**k" (p. 50).

The second act of killing in The Coup takes place against Kush's former president, the now blind King Edumu, whom Ellelloû overthrew and jailed five years back. Once a president of Kush, Edumu becomes a focus for popular discontent, for many blame him for the country's hardships; he lives and "drags the land with him into senility" (29), as the saying goes. The conviction soon grows upon Ellelloû that the King's corrupt rule is the cause of the drought and that his death will cleanse and heal the land. Ellelloû's conviction is rooted in the evil deeds which mark Edumu's rule:

\footnotetext{
The enchanting old villain formerly had taken pride in a barbarous animism of blood and substitution, and in the interstices of French supervision had exercised the fructifying privilege of royal murderousness. Young female attendants especially had fallen victims to his whim. And though their screams under the ax and the smothering pillows had escaped from the palace windows, there was never a shortage of nubile, trembling, onyx-skinned, heavy-breasted replacements, thrust forward not only by the sycophancy of their families but by something suicidal and, beneath their moist terror, voracious within themselves.

(p. 22)
}

In addition to its sensual cruelty, Edumu's rule is also notorious for its unpopularity and corruption. He caused suffering; he undermined the scientific socialism of Kush; he could become the figurehead for a new opposition; and hence his public execution would be an example to the nation of the new regime's seriousness and determination. The King had himself warned Ellelloû that his rule would be long if his heart did not soften. Ultimately, however, the King must be put to death because he has been "an offender against the overarching harmony of common assumptions" (62). He had to step aside because he failed to discern within himself "an idea of Kush," and this made him a political criminal. Quite apart from the sin of parricide, Ellelloû is guilty of excessive pride in taking it upon himself to execute justice on behalf of God as he took it upon himself to behead Edumu, once a father figure. "God's will give my arm strength," he says, in justification of his decision to kill the King (85). Here is the propaganda-filled pronouncement of Ellelloû as a dictator, announcing the Edumu's execution: "The National Honor of Kush and the Will of Allah demand that Justice be Done to this Reactionary and Discredited Exploiter of the Many, who in the course of his Mockery of a Reign appropriated to Himself the Means of Production and the Headwaters of Revenue..." (italics Updike, p. 78).

The execution is public, yet the crowd that came to the execution was small, most of whom were school children who had been granted a day off. The lamb, King Edumu, comes in white robes, hauled by soldiers. He displays unflagging composure in front of death: "People of Wanj, rejoice with me," he tells the crowd. "Today I go to join our ancestors, who live below, who are our blood! These mad soldiers who attempt to govern us are puppets of the ancestors, who dangle them a moment before they toss them aside. If their rule is just, why has the sky-god withheld rain these five years?" (p. 81). The King is butchered like an animal by Colonel Ellelloû himself, who, with an old scimitar from the museum, chops the King's head off in a single stroke. Upon beheading the King, Ellelloû speaks words equally charged with arrogant overtones: "You have witnessed the enactment of a purgation profoundly pleasing to Allah, and deeply beneficial to our green and pleasant land!" (p. 88). Ironically, Ellelloû in turn is not killed upon his own ouster because once the new form is established, the office matters more than the man. Ellelloû, alive, facilitates continuity and orderly transition in government.

Apart from these two acts of killing, and although he conceals it at first, Ellelloû was also secretly responsible for the assassination of General Soba, part of the original revolutionary 
triumvirate - an act which elevated him to the presidency of Kush. Identically, enraged and agonized by the disappearance of his wife Sheba in the cave of the rumored King's head, Ellelloû abruptly orders the killing and raping of busloads of tourists. He not only orders the massacre, but he then demands to know if his orders have been carried out or not. When he later discovers that his soldiers let them go unharmed, Ellelloû describes himself as grief-stricken: "The soldiers, bewildered teen-agers fresh from the peanut fields and the fishing villages, attempted to obey...but the beatings were feeble and the objects of rape...were unappetizing" (p. 237). In addition, at the entrance to the oil refinery located in an area called the 'Ippi Rift Valley', Ellelloû exhorts the crowd to set fire to the city with a crazed vision of holy wars: "Hasten that Day of Disaster, blessed soldiers of our patriotic army and shoot the giant slave of grease mercifully in the throat, and restore this ancient Rift to its pristine desolation, beloved of Allah..." (p. 270).

Ellelloû, here, represents the cast-off "Other", grotesque not only because of the difference he represents but because he is a stereotyped figure, with rhetoric that is a mixture of mindless violence and a fundamentalist invocation of good and evil binaries. Updike seems to say that the order for the killings does not flow out of Ellelloû's character; rather, these actions flow out of his religious ideology. The American emissary and tourists must be killed because they are just servants of imperialism and capitalism which Ellelloû detests. Thus, readers see in Ellelloû evidence of madness and deep-seated malice; a man who considers hatred the source of all strengths. On account of this violence, Africa seems to be experiencing endemic political instability. Where there are no such acts, there are corrupt dictatorships in control, or coups as the only way of changing regimes. The assumption here is that Africans cannot embrace democratic principles of governance. They can only operate under dictatorial regimes, inept despots or military rulers. Updike conveniently avoids talking about the connection between these acts of violence and the colonial intervention adopted mainly by American governments in Kush. Rather, the violence of Ellelloû is depicted as if endemic to African leaders, especially the Muslims among them.

In addition to bloodshed, Ellelloû is continually associated in the narrative with grotesque sensuality. In spite of his political theorizing, Ellelloû's character in the novel is most clearly defined by his relationships with women. These relations are almost wholly on an instinctive voluptuous level, with very little real affection. The four wives and the recently acquired mistress of Ellelloû are all sensual beings upon whom Ellelloû periodically bestows his physical presence. Moreover, Ellelloû's narrative contains statements that betray a white bias. The protagonist's claim that "[i]n Kush we never cease dreaming of intercourse between dark and fair skin, between thick lips and thin lips..." (p. 57) elicits a harsh response from Barry Amis. Amis (1982), who draws on his experiences both as an African-American and as a lecturer in African Studies, argues that "whether or not such a fantasy has any basis in American society, it certainly has none in the African region Updike purports to depict". Moreover, Amis (1982) reacts furiously to the whole portrayal of Africans in that narrative, terming it the "bigoted attitude of some white Americans" (cited in Markle, p. 299).

With this being said, such acts of violence and lechery on the part of Ellelloû should not give Updike a credit to disgrace a whole nation or state. Violence is not restricted to Africans only. Updike should consider the rates of crime and rape that take place in the so-called First World, especially in the United States. They are definitely higher than those taking place in the Third World which is mostly governed by a code of ethics. The occurrence of such acts of violence in Africa, though unjustified by any means, should not be highlighted to become the rule. Generalizations like these will affect and worsen the already distorted image of Africa in the minds 


\section{L: The Southeast Asian Journal of English Language Studies - Vol 26(2): 67 - 80 \\ http://doi.org/10.17576/3L-2020-2602-05}

of Western readers who often take what they read as established facts. Moreover, the fact that Ellelloû is a Muslim does not mean that all Muslims adopt violence or are haunted with sensuality. In fact, Islam calls upon its followers to adopt peace towards all mankind, especially towards nonMuslims. The Ever-Glorious Qur'ān and Sunnah (Prophetic Traditions) are replete with evidence that refute Updike's misconceptions about Islam and Muslims. Ellelloû should not be taken as the norm or as a spokesman for mainstream Islam, and even Africans. His actions should be taken against him alone, without giving offensive generalizations about a certain nation or religion.

\section{CONCLUSION}

John Updike's The Coup defines the relationship between the West and Africa. Africa is a metaphor for moderation and restraint which allows Updike to escape the lavish excesses, selfabsorption, and wasteland that permeate American society. It is also a dramatization of the political events that characterized post-colonial Africa and has little details that showcase the Cold War post-colonial chaos that was sub-Saharan Africa. The novel, moreover, displays some of the fundamentals traits authenticating the American fictions of the African continent: the minimization of realism, lavish exotica and fantasy, imperialist discourse, and indulgence in imagined worlds based on the exploitation of stereotyping plotting and allegorical characterizations. As an imaginative setting, Kush belongs to the tradition of colonial/imperialist discourses on Africa. The images Updike puts before the Western readers in The Coup do little justice to the complexity of Africa and African culture. These images are, by and large, images of misrepresentation. Aspects of this binary opposition of the West and Africa in The Coup are numerous; the West is a technologically advanced world; Africa is a world that has not yet experienced technological development. Nature has been tamed in the West: nature reigns in Africa; the West is a world of science; Africa is a world of magic; peaceful democracy is the political system of the West; the coups and revolutions and rule by force characterize politics in the black continent; the West is a world of health and wealth; Africa is a world of poverty and endemic diseases. Whether this misrepresentation is a result of biased, unbalanced and subjective narration, or is a consequence of a new way of perceiving reality where few corporate giants are creating commercialized representations of Africa in order to maintain their own businesses and ideological agendas, is not the issue. The issue here is that these representations are always focused on the negative, the awkward, the weird and the absurd, the wild and the exotic. The novel, thus, is relatively a faithful reflection of the traditional, stereotypical representations of that continent in Western cultures. Thus, Updike's fictional accounts of Africa are marked by a determining juxtaposition of facts and fantasy, in which fantasy and mythology have the upper hand. This is largely based on the fact that the image of Africa in the popular imagination of the Western world has traditionally been shrouded in a mist of fantasy and prejudice. Yet whether Africa functions as a metaphoric or a realistic setting in The Coup, it is usually portrayed as a dark and mysterious land, the abode of the archetypal alien "Other" — the Black!

\section{ENDNOTES}

1 See, for example, "Out of the Glum Continent"; "Shades of Black"; “Addendum: Excerpts from a Symposium"; and "Through a Continent Darkly". All these essays are collected in Updike's non-fiction collection of essays entitled Picked-Up Pieces. New York. Alfred A. Knopf. 1975. 317-51

2 John Middleton (2002), a renowned British anthropologist and Africanist, argues that Kush was located "south of ancient Egypt along the Nile". The Egyptians called this land "Kush"; the Arabs later called it "Nubia" (46).

3 John Updike. The Coup. New York: Alfred A. Knopf. 1978. All subsequent quotations are from this edition. 


\section{L: The Southeast Asian Journal of English Language Studies - Vol 26(2): 67 - 80 \\ http://doi.org/10.17576/3L-2020-2602-05}

4 This is perhaps Updike's first time to approach the Qur'ān in his work. In The Coup, unlike his later Terrorist for which he cited from two different translations of the Qur'ān, Updike acknowledges his drawing upon the translation of N. J. Dawood, an Iraqi Jewish Orientalist: "The Koran [Qur'ān] quotations are from the Penguin Classics translation by N. J. Dawood" (The Coup, 1978). This translation, however, is known for its partiality and inaccuracy.

5 Qur'ān, Sūrah Al-Insan [The Man, 76:1]. It should be noted here that the mistranslation of this verse, and others, needs much space to be detailed. A close translation of the meaning of the verse can be "Has there [not] come upon man a period of time when he was not a thing [even] mentioned?" (Saheeh International) or: "Has there not been over man a period of time, when he was nothing to be mentioned?" (Muhsin Khan). Dawood's literal translation of the verse is misleading and too far from the real meaning.

\section{REFERENCES}

Achebe, Chinua. (1988). An Image of Africa: Racism in Conrad's Heart of Darkness. In Kimbrough, Robert (Ed.). Heart of Darkness: An Authoritative Text, Backgrounds andSources, Criticism (pp. 251-262). London: W. W Norton and Company,

Conrad, Peter. (2008). Peter Conrad talks women, witchcraft and the election with John Updike. An Interview with John Updike. The Observer, Saturday 25 October. Retrieved March 22, 2019 from https://www.theguardian.com/books/2008/oct/26/john-updike

Cromwell, Adelaide M. (1987). The Fulbright Program in Africa: 1946 to 1986. Annals of the American Academy of Political and Social Science. The Fulbright Experience and Academic Exchanges. Vol. 491, 92-103.

Greiner, Donald J. (1992). John Updike's Novels. Athens: Ohio University Press.

Grusser, John Cullen. (1992). White on Black: Contemporary Literature About Africa. Urbane and Chicago: University of Illinois Press.

Khan,Muhammad Muhsin \& Taqi-ud-Deen Hilali. (1985). Translation of the Meanings of The Noble Qur'ān in the English Language. Madinah: King Fahd Complex for the Printing of the Ever- Glorious Qur'ān.

Lindfors, Bernth, (2001). Hottentot, Bushman, Kaffir: The Making of Racist Stereotypes in $19^{\text {th }}$-Century Britain. In Palmberg, Mai. (Ed.). Encounter Images in the Meetings between Africa and Europe (54-75). Sweden: Nordiska Afrikainstitutet, Uppsala.

McGill, Deborah. (1979). Boy's Life. Harper's Magazine. Vol. 258, 87-89.

Markle, Joyce. (1982). The Coup: Illusions and Insubstantial Impressions. In Macnaughton, William R. (Ed.). Critical Essays on John Updike (pp. 281-302).. Boston: G. K. Hall.

Markovitz, Irving Leonard. (1980). John Updike's Africa. A review of The Coup by John Updike. Canadian Journal of African Studies. Vol. 14 (3), 536-545.

Middleton, John.(2002).Africa: An Encyclopedia for Students. Vol. I. Princeton \& New Jersey: Charles Scribner's Sons.

Pinak, Mohammad Zandy Ali \& Lalbakhsh, Pedram. (2019). Orientalism on the Margins: Inter-Subjective Space in

Edward Granville Browne's A Year amongst the Persians. 3L: The Southeast Asian Journal of English Language

Studies. Vol. 25(3), 33-45.

Prosser, Jay. (2001). Under the Skin of John Updike: Self Consciousness and the Racial Unconscious. PMLA Modern Language Association. Vol. 116 (3), 579-593.

Prosser, Jay. (2006). Updike, Race, and the Postcolonial Project. In Olster, Stacey. (Ed.). The Cambridge Companion to John Updike (pp. 76-90) Cambridge: Cambridge University Press.

Reilly, Charlie, 1978. A Conversation with John Updike". In Plath, James. (Ed.). Conversations with John Updike. Ed.. Jackson: University Press of Mississippi, 1994,124-150.

Schueller, Malini. (1991). Containing the Third World: John Updike's The Coup. Modem Fiction Studies. Vol. 37 (1), 113-128.

The Holy Bible: Containing the Old and New Testaments. (2005). Authorized King James Version Pure Cambridge Edition: Published in Australia.

Updike, John. (1975). Picked-Up Piece., New York: Alfred A. Knopf.

Updike, John. (1978). The Coup. New York: Alfred A. Knopf.

Waite, Robert. (1973). Updikes Visit Black Africa: Strangers in a Strange Land?, In Plath, James. (Ed.). Conversations with John Updike (pp. 67-73). Jackson: University Press of Mississippi. 